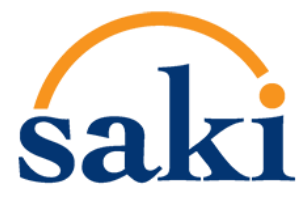

Studi Akuntansi \& Keuangan Indonesia

\title{
Analisis Faktor-Faktor yang Memengaruhi Konservatisme Akuntansi
}

\author{
Nurul Afyani Mumayiz, Cahyaningsih* \\ Prodi S1 Akuntansi, Fakultas Ekonomi dan Bisnis, Universitas Telkom \\ Jl. Telekomunikasi Jl. Terusan Buah Batu, Sukapura, Kec. Dayeuhkolot, Bandung, Jawa Barat 40257
}

Keywords:

Accounting Conservatism, Information Asymmetry, Litigation Risk, Investment Opportunity Set, Capital Intensity

Kata Kunci:

Konservatisme Akuntansi, Asimetri Informasi, Risiko Litigasi, Investment Opportunity Set, Intensitas Modal

*Corresponding Author:

cahyaningsih@telkomuniversity.ac.id

\begin{abstract}
:
This study examines the effect of information asymmetry, litigation risk, investment opportunity set, and capital intensity on accounting conservatism. This study uses consumer goods sector companies listed on the Indonesia Stock Exchange from 2016 to 2018 as a research sample. The data analysis method used is panel data regression analysis using Eviews 9.0 software. The results showed that information asymmetry has a positive effect while litigation risk has a negative effect on accounting conservatism. Investment opportunity set and capital intensity have not to influence accounting conservatism. Suggestions for further researchers to examine prudence, in addition to accounting conservatism. For companies, investors, and creditors are expected to pay attention to the level of information asymmetry and litigation risk because it can affect the level of accounting conservatism applied.
\end{abstract}

\begin{abstract}
Abstrak:
Penelitian ini menguji pengaruh asimetri informasi, risiko litigasi, investment opportunity set, dan intensitas modal terhadap konservatisme akuntansi. Penelitian ini menggunakan perusahaan sektor barang konsumsi yang terdaftar di Bursa Efek Indonesia periode 2016-2018 sebagai sampel penelitian. Metode analisis data yang digunakan adalah analisis regresi data panel dengan menggunakan software Eviews 9.0. Hasil penelitian menunjukkan bahwa asimetri informasi berpengaruh positif sedangkan risiko litigasi berpengaruh negatif terhadap konservatisme akuntansi. Investment opportunity set dan intensitas modal tidak berpengaruh terhadap konservatisme akuntansi. Saran bagi peneliti selanjutnya untuk meneliti prudence, selain konservatisme akuntansi. Bagi perusahaan, investor, dan kreditur diharapkan untuk memerhatikan tingkat asimetri informasi dan risiko litigasi karena hal tersebut dapat memengaruhi tingkat konservatisme akuntansi yang diterapkan.
\end{abstract}


Studi Akuntansi \& Keuangan Indonesia

Pendahuluan

Konservatisme diartikan sebagai sikap kehati-hatian terhadap sesuatu yang tidak pasti dan memastikan risiko yang dihadapi dalam bisnis dapat dipertimbangkan secara memadai (Financial Accounting Standards Board, 1980). Konservatisme akuntansi digunakan untuk membatasi perilaku untuk melebih-lebihkan keuntungan, menghindari perilaku oportunistik manajer, dan dapat menghindari suatu ketidakpastian (Andreas et al., 2017).

Aset dan kewajiban terkadang berada dalam ketidakpastian, sehingga metode historis digunakan sebagai pengukuran untuk menghindari terjadinya kelebihan aset bersih. Hal tersebut mengakibatkan adanya penerapan prinsip konservatisme di dalam perusahaan. Namun, konservatisme akuntansi tidak diatur lagi di dalam International Financial Report Standards (IFRS), hal tersebut dikarenakan nilai informasi akuntansi yang relevan untuk masa depan lebih ditekankan di dalam IFRS, sedangkan konservatisme menekankan keandalan informasi akuntansi dari masa lalu (Zelmiyanti, 2014).

Prinsip konservatisme di dalam IFRS diganti menjadi prinsip prudence. Prinsip prudence mengurangi pengakuan yang tinggi terhadap kewajiban dan beban pada laporan keuangan (Zelmiyanti, 2014). Selain itu, karakteristik IFRS yang menggunakan principle based membutuhkan professional judgment dalam penilaian suatu akun. Professional judgment akan meningkatkan optimisme suatu perusahaan dikarenakan perusahaan dapat mengakui perubahan nilai suatu akun berdasarkan fair value dan optimis perubahan nilai tersebut akan terealisasi (Samuel dan Juliarto, 2015). Hal itu dapat menimbulkan potensi terjadinya manipulasi pelaporan keuangan. Menurut Hendriksen dan Breda (2014), pemilik perusahaan pada dasarnya optimis dengan perusahaannya sendiri, sehingga kecenderungan akuntan terhadap pesimisme (konservatisme) dalam pelaporan keuangan dapat mengimbangi optimisme tersebut. Oleh karena itu, tujuan penelitian ini adalah untuk menginvestigasi apakah perusahaan masih menerapkan prinsip konservatisme.

Penerapan konservatisme yang kurang memadai pada penyajian laporan keuangan dapat menimbulkan skandal akuntansi. Manipulasi laporan keuangan merupakan salah satu skandal akuntansi yang masih sering terjadi di Indonesia. Beberapa kasus yang terjadi diantaranya pada PT 
Studi Akuntansi \& Keuangan Indonesia

Tiga Pilar Sejahtera Food Tbk, PT Kimia Farma Tbk, dan PT Indofarma Tbk. PT Tiga Pilar Sejahtera Food melakukan penggelembungan dana senilai Rp4 triliun dan penggelembungan pendapatan senilai Rp662 miliar serta penggelembungan lain senilai Rp329 miliar (Wareza, 2019). PT Kimia Farma mencatat laba sebesar Rp132 miliar, sedangkan laba yang sebenarnya sebesar Rp99 miliar (Syahrul, 2003). Selain itu, PT Indofarma mencatat kerugian sekitar Rp68 miliar pada tahun 2003, namun setelah diaudit kerugian yang dialami menjadi sekitar Rp129,5 miliar (Riza, 2004). Kasus penggelembungan atau overstatement yang terjadi pada perusahaan di Indonesia disebabkan karena kurangnya kehati-hatian dalam tindakan pelaporan keuangan. Oleh sebab itu, penyajian informasi pada laporan keuangan tersebut keliru dan mampu menyesatkan penggunanya.

Ada beberapa faktor yang dapat memengaruhi konservatisme, diantaranya asimetri informasi, risiko litigasi, investment opportunity set (IOS), dan intensitas modal. Beberapa peneliti yang telah melakukan penelitian tentang konservatisme akuntansi diantaranya Isniawati et al. (2016), Kartika et al. (2015), Pratama et al. (2016), Saputra (2016), Andreas et al. (2017), Dwitayanti dan Fahlefi (2015), Purnama dan Daljono (2013), serta Sinambela dan Almilia (2018). Isniawati et al. (2016) menemukan asimetri informasi berpengaruh positif terhadap konservatisme akuntansi sedangkan Kartika et al. (2015) tidak menemukan adanya pengaruh asimetri informasi terhadap konservatisme akuntansi. Saputra (2016) menemukan risiko litigasi berpengaruh positif terhadap konservatisme akuntansi, sedangkan Pratama et al. (2016) tidak menemukan adanya pengaruh risiko litigasi terhadap konservatisme akuntansi. Andreas et al. (2017) menemukan IOS berpengaruh positif terhadap konservatisme akuntansi sedangkan Dwitayanti dan Fahlefi (2015) tidak menemukan adanya pengaruh IOS terhadap konservatisme akuntansi. Purnama dan Daljono (2013) menemukan intensitas modal berpengaruh positif terhadap konservatisme akuntansi, sedangkan Sinambela dan Almilia (2018) tidak menemukan adanya pengaruh intensitas modal terhadap konservatisme akuntansi.

Berdasarkan beberapa fenomena yang terjadi terkait overstatement dan adanya inkonsistensi antara hasil penelitian terdahulu terhadap konservatisme akuntansi, maka dilakukan penelitian mengenai pengaruh asimetri informasi, risiko litigasi, investment opportunity set, dan intensitas modal terhadap konservatisme akuntansi pada perusahaan sektor barang konsumsi yang terdaftar di Bursa Efek Indonesia periode 2016-2018. 


\section{Telaah Literatur dan Pengembangan Hipotesis}

\section{Teori Keagenan}

Teori keagenan adalah teori berkaitan dengan suatu perjanjian antara principal dan agent untuk memberikan jasa atau melakukan kegiatan-kegiatan dan mendelegasikan wewenang kepada agent tersebut dalam mengambil keputusan (Jensen dan Meckling, 1976). Agent diberikan suatu wewenang oleh pemilik (principal) untuk melakukan kegiatan operasional perusahaan, akibatnya agent akan mempunyai informasi yang lebih dibandingkan pemilik perusahaan (Samuel dan Juliarto, 2015).

Masalah keagenan dapat terjadi dikarenakan adanya pertentangan kepentingan antara manajerial (agent) dengan stakeholder (principal). Manajemen tidak hanya melalukan tindakan untuk kepentingan stakeholder, tetapi juga untuk kepentingan kreditur dan pemerintah. Namun, manajemen terkadang bertindak untuk kepentingan sendiri tanpa memikirkan dampak bagi pihak principal (Purnama dan Daljono, 2013). Oleh karena itu, manajemen perlu menyeimbangkan kepentingan sendiri dan kepentingan principal salah satunya dengan berhati-hati dalam menyajikan laporan keuangan (konservatisme akuntansi), sehingga tidak terjadi konflik kepentingan dan ketidakseimbangan informasi antara agent dan principal.

\section{Konservatisme Akuntansi}

Konservatisme juga diartikan harus melaporkan nilai paling rendah aktiva dan pendapatan dan tertinggi untuk kewajiban dan beban atau dengan maksud lain beban segera diakui dan pendapatan tidak diakui segera (Hendriksen dan Breda, 2014). Penerapan prinsip konservatisme sudah mengalami banyak perkembangan. Prinsip konservatisme muncul dikarenakan adanya tuntutan pengguna laporan keuangan terhadap perusahaan yang mengalami kerugian akibat pihak manajemen yang terlalu optimis menentukan nilai aktiva perusahaan. Oleh karena itu, untuk mengurangi hal tersebut disarankan untuk menerapkan prinsip konservatisme dalam perusahaan (Zelmiyanti, 2014). Menurut Hendriksen dan Breda (2014), terdapat beberapa argumen mengenai konservatisme sebagai berikut. 
Studi Akuntansi \& Keuangan Indonesia

a. Argumen pertama mengatakan bahwa pemilik perusahaan pada dasarnya optimis dengan perusahaannya sendiri, sehingga kecenderungan akuntan terhadap pesimisme (konservatisme) dalam pelaporan keuangan dapat mengimbangi optimisme tersebut.

b. Argumen kedua mengatakan bahwa kelebihan penyajian laba lebih rawan dibandingkan kurang saji laba untuk bisnis dan pemiliknya.

c. Argumen ketiga mengatakan konservatisme didasarkan pada asumsi bahwa akuntan memliki akses lebih banyak daripada yang dikomunikasikan kepada investor dan kreditor, dan akuntan dihadapkan dua risiko dalam melaksanakan audit yaitu risiko yang dilaporkan menjadi tidak benar dan yang tidak dilaporkan bisa menjadi benar.

\section{Asimetri Informasi}

Asimetri informasi adalah keadaan saat satu pihak mempunyai informasi yang lebih daripada yang lain (Nidar, 2016). Asimetri informasi terjadi ketika informasi yang dimiliki pihak manajemen sebagai penyedia informasi berbeda dengan para pengguna informasi (Kartika et al., 2015). Terdapat dua tipe dalam asimetri informasi yaitu adverse selection dan moral hazard. Asimetri informasi yang timbul akibat satu pihak atau lebih melakukan transaksi usaha atau transaksi usaha potensial, mempunyai informasi yang lebih dibandingkan yang lain disebut adverse selection. Hal tersebut dapat terjadi antara para manajer perusahaan dan pihak dalam (insiders) lainnya yang memahami keadaan terkini dan prospek perusahaan yang akan datang dibandingkan para investor luar (Susanti et al., 2016). Namun, asimetri informasi yang timbul akibat satu pihak atau lebih melakukan transaksi usaha, atau transaksi usaha potensial, dan dapat mengamati kegiatan mereka dalam menyelesaikan transaksi tersebut dibandingkan pihak lainnya disebut tipe moral hazard. Hal tersebut timbul akibat adanya pemisahan pemilikan dengan pengendalian (Susanti et al., 2016).

\section{Risiko Litigasi}

Risiko litigasi merupakan risiko yang terkait dengan perusahaan dan memungkinkan timbulnya ancaman litigasi oleh kreditor, investor, dan regulator dengan perusahaan yang merasa dirugikan. Jika hukum yang ditegakkan dalam lingkungan pasar modal dilaksanakan dengan baik maka intensitas risiko litigasi semakin tinggi (Savitri, 2016). 
Studi Akuntansi \& Keuangan Indonesia

Risiko litigasi dapat mendukung manajer melakukan pelaporan keuangan perusahaan lebih konservatif. Semakin tinggi risiko ancaman litigasi, maka semakin kuat dorongan manajer dalam menerapkan konservatisme akuntansi (Ramadhoni et al., 2014). Risiko litigasi merupakan risiko yang dapat menimbulkan biaya yang banyak karena berhubungan dengan masalah hukum. Semakin tinggi laba, maka potensi risiko litigasi semakin tinggi pula sehingga manajer akan melaporkan keuangan secara konservatif untuk menghindari kerugian akibat litigasi tersebut (Ramadhoni et al., 2014).

\section{Investment Opportunity Set (IOS)}

Investment opportunity set ialah kumpulan keputusan investasi yang dimiliki berwujud aset dan pilihan investasi masa yang akan datang untuk mendapatkan keuntungan yang lebih banyak. Investment opportunity set menunjukkan biaya yang dikeluarkan guna mendapatkan tingkat pengembalian yang tinggi di masa akan datang (Aristantia dan Putra, 2015). Kesempatan investasi di masa depan tidak semua dapat dilaksanakan oleh setiap perusahaan, akibatnya pengeluaran yang dialami perusahaan akan lebih tinggi.

\section{Intensitas Modal}

Intensitas modal menggambarkan tingkat modal yang diperlukan dalam menghasilkan pendapatan dan menjadi acuan sebagai indikator perusahaan dalam hal merebutkan pasar. Perusahaan akan cenderung mengurangi laba ketika perusahaan tersebut memiliki modal yang padat. Hal tersebut dikarenakan mempunyai biaya politis yang cukup tinggi (Purnama dan Daljono, 2013). Menurut Savitri (2016), salah satu indikator dari political cost hypothesis adalah intensitas modal. Suatu perusahaan dapat dipastikan besar, jika aset yang dipakai pada operasi perusahaan juga besar untuk menghasilkan produk.

Tingkat efisiensi penggunaan seluruh aset dalam menghasilkan volume penjualan perusahaan digambarkan melalui intensitas modal yang dimiliki. Penggunaan seluruh aktiva akan semakin efisien jika rasio intensitas modal juga tinggi. Hal ini akan berguna bagi kreditor, pemilik perusahaan dan manajemen perusahaan (Purnama dan Daljono, 2013).

\section{Pengembangan Hipotesis}

Asimetri Informasi dan Konservatisme Akuntansi 
Studi Akuntansi \& Keuangan Indonesia

Suatu kondisi ketika pihak internal lebih memahami keadaan dan prospek perusahaan di masa akan datang dibandingkan pihak eksternal disebut sebagai asimetri informasi. Hal tersebut dapat menimbulkan pihak internal akan memanfaatkan keadaan tersebut dan tentunya akan memengaruhi keputusan investor dalam membeli sekuritas perusahaan. Oleh karena itu, untuk mengendalikan masalah tersebut maka perusahaan akan berhati-hati dalam melaporkan keuangannya (Kartika et al., 2015).

Peneliti menduga asimetri informasi berpengaruh positif terhadap konservatisme akuntansi. Tingkat asimetri informasi yang tinggi maka menimbulkan penerapan konservatisme yang tinggi pula. Hal tersebut dikarenakan semakin besar perbedaan informasi antara pihak internal dengan eksternal menyebabkan pihak internal semakin berhati-hati melaporkan laporan keuangannya, sehingga investor atau pihak eksternal perusahaan akan memberikan keputusan yang berdampak baik bagi perusahaan. Manajemen juga akan memilih understated laba daripada overstated, karena dianggap overstated akan menyesatkan investor (pihak eksternal). Beberapa peneliti telah menguji pengaruh asimetri informasi terhadap konservatisme akuntansi. Isniawati et al. (2016) serta Lafond dan Watts (2008) mengemukakan asimetri informasi berpengaruh positif terhadap konservatisme akuntansi. Asimetri informasi akan meningkat ketika investasi tumbuh dengan baik dan untuk mempertahankan hal tersebut maka perusahaan cenderung meningkatkan penerapan konservatisme. Berdasarkan argumentasi tersebut, maka hipotesis yang diajukan yaitu sebagai berikut.

\section{H1. Asimetri informasi berpengaruh positif terhadap konservatisme akuntansi.}

\section{Risiko Litigasi dan Konservatisme Akuntansi}

Risiko litigasi ialah risiko yang terkait dengan perusahaan dan memungkinkan timbulnya litigasi oleh pihak yang memiliki kepentingan. Risiko litigasi menimbulkan biaya yang banyak karena berhubungan dengan persoalan hukum. Risiko litigasi mencerminkan kemungkinan terjadinya tuntutan dari pihak yang merasa dirugikan, sehingga perusahaan dapat mengeluarkan biaya yang tinggi. Risiko litigasi dapat memicu seorang manajer untuk lebih konservatif dalam pelaporan keuangan, maka tingginya risiko litigasi yang dihadapi perusahaan akan mengakibatkan penerapan konservatisme yang tinggi pula (Saputra, 2016). 
Studi Akuntansi \& Keuangan Indonesia

Peneliti menduga risiko litigasi berpengaruh positif terhadap konservatisme akuntansi. Penegakan hukum yang tinggi dalam lingkungan pasar modal maka intensitas potensi risiko litigasi yang terjadi juga tinggi. Oleh sebab itu, manajer akan terdorong untuk lebih konservatif dalam pelaporan keuangan agar tidak mengeluarkan biaya yang besar. Beberapa peneliti telah menguji pengaruh risiko litigasi terhadap konservatisme akuntansi. Saputra (2016) dan Ramadhoni et al. (2014) menyatakan risiko litigasi berpengaruh positif terhadap konservatisme akuntansi. Penegakan hukum dalam lingkungan akuntansi menuntut manajer lebih memperhatikan praktik akuntansi supaya tuntutan hukum dapat dihindari. Jika perusahaan melakukan pelanggaran maka akan menimbulkan litigasi, sehingga perusahaan akan terdorong untuk lebih konservatif dalam penyajian laporan keuangan. Oleh sebab itu, hipotesis yang diajukan sebagai berikut.

H2. Risiko litigasi berpengaruh positif terhadap konservatisme akuntansi.

Investment Opportunity Set dan Konservatisme Akuntansi

Kumpulan keputusan investasi yang dimiliki berwujud aset dan pilihan investasi masa yang akan datang untuk mendapatkan keuntungan yang lebih banyak disebut investment opportunity set. Investment opportunity set menunjukkan biaya yang dikeluarkan untuk mendapatkan tingkat pengembalian yang tinggi di masa akan datang (Aristantia dan Putra, 2015). Kesempatan investasi di masa depan tidak semua dapat dilaksanakan oleh setiap perusahaan, akibatnya pengeluaran yang dialami perusahaan akan lebih tinggi daripada nilai kesempatan yang hilang. Oleh karena itu, perusahaan membutuhkan keputusan yang tepat terhadap sesuatu yang tidak pasti tersebut dan risiko yang akan dihadapi, sehingga manajer akan cenderung menerapkan konservatisme agar terhindar dari ketidakpastian tersebut (Andreas et al., 2017).

Peneliti menduga bahwa investment opportunity set berpengaruh positif terhadap konservatisme akuntansi. Kesempatan investasi perusahaan yang tinggi maka menimbulkan tingkat ketidakpastian yang dihadapi perusahaan juga tinggi. Oleh karena itu, perusahaan akan cenderung konservatif agar terhindar dari ketidakpastian dan risiko yang akan dihadapi perusahaan di masa depan. Beberapa peneliti telah menguji pengaruh investment opportunity set terhadap konservatisme akuntansi. Andreas et al. (2017) dan Saputri (2013) menyatakan investment opportunity set 
Studi Akuntansi \& Keuangan Indonesia

berpengaruh positif terhadap konservatisme akuntansi. Berdasarkan argumentasi tersebut, maka hipotesis yang diajukan adalah sebagai berikut.

H3. Investment opportunity set berpengaruh positif terhadap konservatisme akuntansi.

Intensitas Modal dan Konservatisme Akuntansi

Intensitas modal menunjukkan tingkat modal perusahaan berbentuk aktiva. Intensitas modal menunjukkan jumlah modal yang diperlukan untuk mendapatkan pendapatan sehingga menjadi indikator prospek perusahaan dalam merebutkan pasar (Purnama dan Daljono 2013). Jumlah aset yang besar guna mendapatkan penjualan produk maka dapat dipastikan perusahaan tersebut besar. Perusahaan dengan padat modal melakukan pelaporan yang lebih konservatif dengan tujuan menghindari biaya politis yang tinggi karena perusahaan besar akan lebih diawasi pemerintah (Savitri, 2016).

Peneliti menduga bahwa intensitas modal berpengaruh positif terhadap konservatisme. Perusahaan dengan padat modal mempunyai biaya politis yang lebih tinggi. Oleh karena itu, biaya politis dapat dihindari perusahaan dengan pelaporan keuangan yang lebih konservatif. Beberapa peneliti telah menguji pengaruh intensitas modal terhadap konservatisme akuntansi. Susanto dan Ramadhan (2016), Purnama dan Daljono (2013), serta Alfian dan Sabeni (2013) menemukan intensitas modal berpengaruh positif terhadap konservatisme akuntansi. Oleh sebab itu, hipotesis yang diajukan yaitu sebagai berikut.

H4. Intensitas modal berpengaruh positif terhadap konservatisme akuntansi.

\section{Kerangka Pemikiran}

\section{Gambar 1. Kerangka Pemikiran}

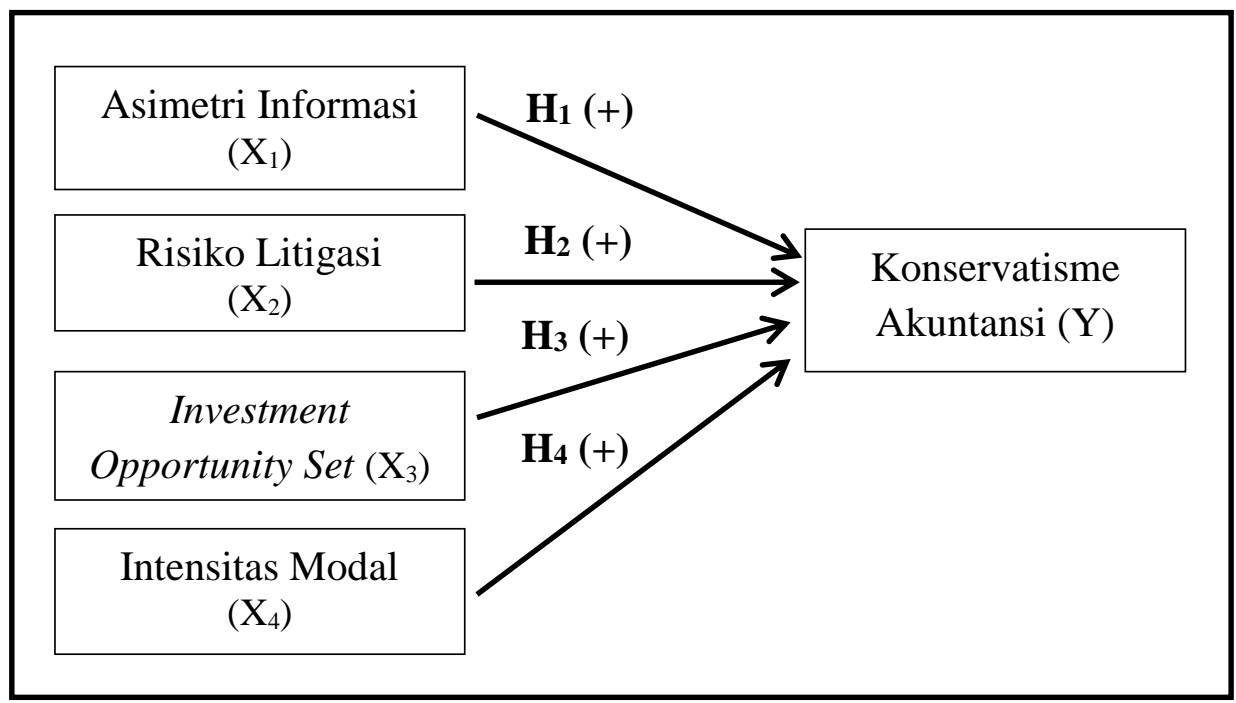




\section{Metode Penelitian}

Metode penelitian ini adalah metode penelitian kuantitatif. Menurut Sujarweni (2015), penelitian kuantitatif merupakan bentuk penelitian yang menggunakan prosedur-prosedur statistik. Penelitian kuantitatif menggunakan data yang berupa angka (Sujarweni, 2015). Menurut sumbernya, data yang digunakan pada penelitian ini adalah data sekunder. Menurut Hermawan dan Yusran (2017), data sekunder diartikan sebagai struktur data historis yang telah dikumpulkan oleh pihak lain yang dapat diperoleh dari dalam perusahaan, berbagai internet websites, perpustakaan umum dan lainlain.

\section{Populasi dan Sampel}

Populasi yang digunakan adalah perusahaan sektor barang konsumsi yang terdaftar di Bursa Efek Indonesia periode 2016-2018. Adapun jumlah perusahaan sektor barang konsumsi yang terdaftar di Bursa Efek Indonesia periode 2016-2018 sebanyak 57 perusahaan. Teknik sampling yang digunakan adalah nonprobability sampling dengan jenis purposive sampling. Purposive sampling merupakan teknik sampling dengan kriteria-kriteria tertentu (Sujarweni, 2015:88). Berikut merupakan kriteria-kriteria penentuan sampel penelitian.

1. Perusahaan sektor barang konsumsi yang terdaftar secara konsisten di Bursa Efek Indonesia periode 2016-2018.

2. Perusahaan sektor barang konsumsi yang mempublikasikan laporan keuangan yang telah diaudit dan laporan tahunan secara konsisten selama periode 2016-2018.

\section{Tabel 1. Perolehan Sampel Penelitian}

\begin{tabular}{|c|l|c|}
\hline No. & \multicolumn{1}{|c|}{ Kriteria Pemilihan Sampel } & Total \\
\hline 1 & $\begin{array}{l}\text { Perusahaan sektor barang konsumsi yang secara konsisten terdaftar di } \\
\text { Bursa Efek Indonesia periode 2016-2018. }\end{array}$ & 44 \\
\hline 2 & $\begin{array}{l}\text { Perusahaan sektor barang konsumsi yang tidak mempublikasikan laporan } \\
\text { keuangan yang telah diaudit dan laporan tahunan secara konsisten selama } \\
\text { periode 2016-2018. }\end{array}$ & $(7)$ \\
\hline \multicolumn{2}{|l|}{ Jumlah Sampel } & $\mathbf{1 1 1}$ \\
\hline \multicolumn{2}{|l|}{ Total Observasi (37 sampel x 3 tahun) } \\
\hline
\end{tabular}


Studi Akuntansi \& Keuangan Indonesia

Berdasarkan kriteria tersebut maka jumlah sampel yang digunakan adalah 37 perusahaan, dengan periode waktu penelitian selama tiga tahun maka diperoleh total observasi sebanyak 111 observasi.

\section{Pengukuran dan Operasionalisasi Variabel}

Konservatisme Akuntansi $(Y)$

Konservatisme diartikan sebagai tindakan melaporkan nilai aktiva dan pendapatan paling rendah serta kewajiban dan beban paling tinggi atau dengan maksud lain, beban segera diakui dan pendapatan diakui nanti (Hendriksen dan Breda, 2014). Pengukuran konservatisme akuntansi yang digunakan adalah pengukuran yang dikembangkan oleh Zhang (2007). Pengukuran ini menggunakan conv_accrual dengan membagi akrual nonoperasi dengan total aset dan dikalikan -1.

$$
\text { conv_accrual }=\frac{\text { Nonoperating Accrual }}{\text { Total Asset }} \times-1
$$

Keterangan:

Non Operating Accrual $=$ Operating Accruals $-\Delta$ Account Receivable $-\Delta$ Inventories $-\Delta$ Prepaid

$$
\text { Expenses }+\Delta \text { Account Payable }+\Delta \text { Tax Payable }
$$

Operating Accrual $\quad=$ Net Income + Depreciation - Cash Flow from Operations

Jika tidak terdapat Cash Flow from Operations, maka:

Operating Accrual $\quad=$ Net income + depreciation - funds from operations $+\Delta$ current assets +

$$
\Delta \text { debt }-\Delta \text { current liabilities }-\Delta \text { cash }
$$

Asimetri Informasi $\left(X_{l}\right)$

Menurut Nidar (2016), asimetri informasi ialah keadaan saat satu pihak mempunyai informasi yang lebih daripada yang lain. Pengukuran asimetri informasi yang digunakan penelitian ini berfokus pada adverse selection yang menunjukkan perbedaan informasi antara pihak manajer dengan investor dalam pengambilan keputusan. Proksi asimetri informasi yang digunakan adalah bid-ask spread. Bidask spread diartikan sebagai selisih antara harga beli paling tinggi dengan harga jual terendah saham trader (Venkatesh dan Chiang, 1986; dalam Kartika et al., 2015).

$$
\operatorname{Spread}_{j, t}=\frac{a s k_{j, t}-b i d_{j, t}}{\left(\frac{a s k_{j, t}+b_{j, t}}{2}\right)}
$$


Studi Akuntansi \& Keuangan Indonesia

Keterangan:

$A s k_{j, t}=$ Harga penawaran saham tertinggi perusahaan $\mathrm{j}$ pada tahun ke-t

$B i d_{j, t}=$ Harga permintaan saham terendah perusahaan $\mathrm{j}$ pada tahun ke- $\mathrm{t}$

\section{Risiko Litigasi $\left(X_{2}\right)$}

Savitri (2016) menjelaskan risiko litigasi merupakan risiko yang terkait dengan perusahaan yang dapat menimbulkan ancaman litigasi oleh kreditor, investor, dan regulator dengan perusahaan yang merasa dirugikan. Risiko litigasi diukur dengan Debt to Equity Ratio (DER). Jika Debt to Equity Ratio tinggi maka risiko litigasi yang dihadapi perusahaan semakin besar (Pratama et al., 2016).

$$
D E R=\frac{\text { Total Hutang }}{\text { Total Ekuitas }}
$$

\section{Investment Opportunity $\operatorname{Set}\left(X_{3}\right)$}

Kumpulan keputusan investasi yang dimiliki berwujud aset dan pilihan investasi masa akan datang untuk mendapatkan keuntungan yang lebih banyak disebut investment opportunity set. Investment opportunity set menggambarkan biaya yang dikeluarkan guna mendapatkan tingkat pengembalian yang tinggi di masa akan datang (Aristantia dan Putra, 2015).

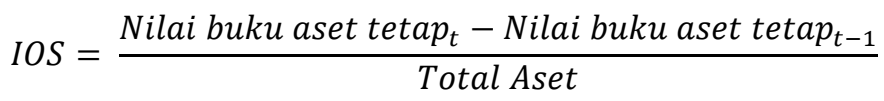

\section{Intensitas Modal $\left(X_{4}\right)$}

Intensitas modal dapat digunakan untuk menjelaskan efisiensi penggunaan seluruh aset untuk menghasilkan volume penjualan suatu perusahaan. Penggunaan seluruh aktiva untuk memperoleh penjualan akan semakin efisien jika rasio intensitas modal semakin tinggi. Hal ini akan berguna bagi kreditor, pemilik perusahaan dan manajemen perusahaan (Purnama dan Daljono, 2013).

$$
I M=\frac{\text { Penjualan }}{\text { Total aset }}
$$

\section{Metode Analisis Data}

Analisis data yang digunakan peneliti adalah analisis kuantitatif menggunakan teknik perhitungan statistik deskriptif dan analisis regresi data panel. Peneliti menggunakan aplikasi Eviews 9.0 untuk menganalisis data dan menggunakan metode analisis regresi data panel. Berikut merupakan persamaan regresi model data panel yang digunakan dalam penelitian ini. 
Studi Akuntansi \& Keuangan Indonesia

$$
Y=\alpha+\beta_{1} X_{1 i t}+\beta_{2} X_{2 i t}+\beta_{3} X_{3 i t}+\beta_{4} X_{4 i t}+e
$$

Keterangan:

$\begin{array}{ll}\mathrm{Y} & =\text { Konservatisme akuntansi } \\ \alpha & =\text { Konstanta } \\ \beta_{1}, \beta_{2}, \beta_{3}, \beta_{4} & =\text { Koefisien regresi masing-masing variabel independen } \\ X_{1 i t} & =\text { Asimetri informasi pada perusahaan } i \text { di tahun ke- } t \\ X_{2 i t} & =\text { Risiko litigasi pada perusahaan } i \text { di tahun ke- } t \\ X_{3 i t} & =\text { Investment opportunity set pada perusahaan } i \text { di tahun ke- } t \\ X_{4 i t} & =\text { Intensitas modal pada perusahaan } i \text { di tahun ke- } t \\ e & =\text { error term }\end{array}$

\section{Hasil dan Diskusi}

\section{Statistik Deskriptif}

Statistik deskriptif mencerminkan berbagai karakteristik data dari suatu sampel. Statistik deskriptif seperti mean, standar deviasi, minimum, dan maximum yang berbentuk analisis angka (Sujarweni, 2015:113). Total observasi penelitian ini sebanyak 111 data observasi dari 37 perusahaan selama periode waktu penelitian tiga tahun. Namun, terdapat beberapa data yang tidak dapat digunakan karena memiliki nilai ekstrem. Peneliti melakukan uji outlier menggunakan aplikasi Eviews 9.0 dengan melihat nilai studentized residual. Data outlier pada penelitian ini sebanyak 5 observasi, sehingga total observasi setelah dilakukan uji outlier sebanyak 106 observasi. Adapun hasil pengujian statistik deskriptif dijelaskan pada tabel 2 berikut.

Tabel 2. Hasil Pengujian Statistik Deskriptif

\begin{tabular}{|l|c|c|c|c|c|}
\hline & $\begin{array}{c}\text { Konservatisme } \\
(\mathbf{Y})\end{array}$ & $\begin{array}{c}\text { Asimetri } \\
\text { Informasi (X1) }\end{array}$ & $\begin{array}{c}\text { Risiko } \\
\text { Litigasi (X2) }\end{array}$ & $\begin{array}{c}\text { Investment } \\
\text { Opportunity Set (X3) }\end{array}$ & $\begin{array}{c}\text { Intensitas } \\
\text { Modal (X4) }\end{array}$ \\
\hline Mean & 0,08119 & 0,06785 & 0,96583 & 0,02837 & 1,09348 \\
\hline Maximum & 0,42983 & 2,00000 & 11,35041 & 0,43128 & 3,10476 \\
\hline Minimum & $-0,19645$ & 0,00030 & 0,08330 & $-0,26661$ & 0,05972 \\
\hline Std. Dev. & 0,17072 & 0,27321 & 1,23300 & 0,06513 & 0,58212 \\
\hline
\end{tabular}


Studi Akuntansi \& Keuangan Indonesia

Berdasarkan tabel 2 tersebut menunjukkan bahwa konservatisme akuntansi, asimetri informasi, risiko litigasi, dan investment opportunity set memiliki nilai rerata lebih kecil dari nilai deviasi standar berarti data asimetri informasi, risiko litigasi, dan investment opportunity set perusahaan sektor barang konsumsi yang terdaftar di Bursa Efek Indonesia periode 2016-2018 tidak berkelompok atau bervariasi. Adapun variabel intensitas modal memiliki nilai rerata lebih besar dari nilai deviasi standar menunjukkan bahwa data intensitas modal perusahaan sektor barang konsumsi yang terdaftar di Bursa Efek Indonesia periode 2016-2018 berkelompok atau tidak bervariasi.

\section{Uji Asumsi Klasik}

Uji Normalitas

\section{Gambar 2. Hasil Uji Normalitas}

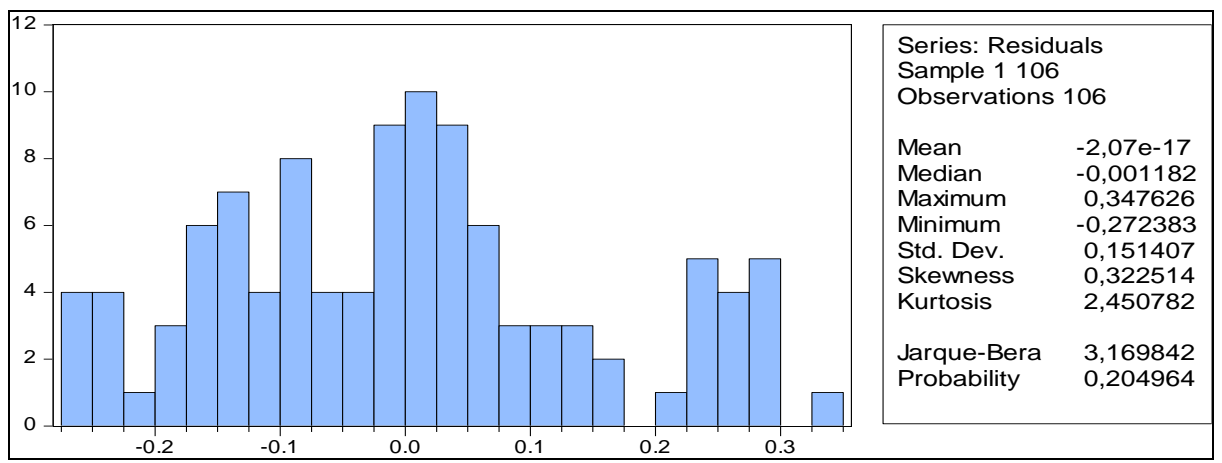

Berdasarkan gambar 2, diketahui bahwa nilai probabilitas Jarque-Bera 0,204964 lebih besar dari 0,05. Oleh sebab itu, dapat diartikan bahwa data terdistribusi normal.

\section{Uji Heteroskedastisitas}

Tabel 3. Hasil Uji Heteroskedastisitas

\begin{tabular}{|llll|}
\hline Heteroskedasticity Test: White & & \\
\hline \hline F-statistic & 0,447498 & Prob. F(4,101) & 0,7740 \\
Obs*R-squared & 1,845890 & Prob. Chi-Square(4) & 0,7641 \\
Scaled explained SS & 1,215651 & Prob. Chi-Square(4) & 0,8755 \\
\hline
\end{tabular}

Berdasarkan tabel 3, diketahui nilai probabilitas Chi-Square 0,7641 lebih besar dari 0,05.

Oleh sebab itu, model yang digunakan tidak terjadi gejala heteroskedastisitas dan layak digunakan untuk memprediksi konservatisme akuntansi berdasarkan variabel asimetri informasi, risiko litigasi, investment opportunity set, dan intensitas modal.

\section{Uji Autokorelasi}


Tabel 4. Hasil Uji Autokorelasi

\begin{tabular}{|l|r|}
\hline Mean dependent var & 0,081188 \\
\hline S.D. dependent var & 0,170724 \\
\hline Akaike info criterion & $-0,678697$ \\
\hline Schwarz criterion & $-0,553063$ \\
\hline Hannan-Quinn criter. & $-0,627776$ \\
\hline Durbin-Watson stat & 2,207197 \\
\hline
\end{tabular}

Berdasarkan tabel Durbin Watson signifikansi 5\% dengan jumlah observasi 106 dan jumlah variabel independen $4(\mathrm{k}=4)$, maka nilai $\mathrm{du}=1,7624 \mathrm{dan} \mathrm{dl}=1,6061$. Nilai $\mathrm{dw}=2,207197$ lebih besar dari nilai du $=1,7624$ dan lebih kecil dari $4-\mathrm{du}(4-1,7624)=2,2376$ sehingga didapatkan du $<\mathrm{dw}<4-\mathrm{du}$, yaitu $1,7624<2,207197<2,2376$. Berdasarkan hasil tersebut, maka dalam model ini tidak terjadi autokorelasi positif maupun negatif.

\section{Uji Multikolinearitas}

Tabel 5. Hasil Uji Multikolinearitas

\begin{tabular}{|cccc|}
\hline Variable & $\begin{array}{c}\text { Coefficient } \\
\text { Variance }\end{array}$ & $\begin{array}{c}\text { Uncentered } \\
\text { VIF }\end{array}$ & $\begin{array}{c}\text { Centered } \\
\text { VIF }\end{array}$ \\
\hline \hline C & 0,001238 & 5,504960 & NA \\
X1 & 0,004612 & 1,610990 & 1,516567 \\
X2 & 0,000224 & 2,432954 & 1,502356 \\
X3 & 0,056076 & 1,248804 & 1,048018 \\
X4 & 0,000675 & 4,598099 & 1,007878 \\
\hline
\end{tabular}

Berdasarkan tabel 5, diperoleh semua nilai VIF lebih kecil dari 10. Oleh karena itu, dapat diartikan bahwa model regresi tidak terdapat korelasi antara variabel independen atau tidak terjadi multikolinearitas.

\section{Pemilihan Model Regresi Data Panel}

Berdasarkan hasil pengujian pemilihan model regresi data panel yang telah dilakukan, maka metode regresi data panel yang paling tepat digunakan adalah model random effect. Berikut merupakan tabel 6 hasil pengujian metode random effect. 
Tabel 6. Hasil Uji Random Effect

\begin{tabular}{|c|c|c|c|c|}
\hline \multicolumn{5}{|c|}{$\begin{array}{l}\text { Method: Panel EGLS (Cross-section random effects) } \\
\text { Sample: } 20162018 \\
\text { Periods included: } 3 \\
\text { Total panel observations: } 106\end{array}$} \\
\hline Variable & Coefficient & Std. Error & t-Statistic & Prob. \\
\hline $\mathrm{C}$ & 0,069227 & 0,041689 & 1,660556 & 0,0999 \\
\hline $\mathrm{X} 1$ & 0,168415 & 0,056555 & 2,977894 & 0,0036 \\
\hline $\mathrm{X} 2$ & $-0,046491$ & 0,013501 & $-3,443609$ & 0,0008 \\
\hline X3 & $-0,228929$ & 0,201965 & $-1,133507$ & 0,2597 \\
\hline $\mathrm{X} 4$ & 0,048953 & 0,031222 & 1,567925 & 0,1200 \\
\hline \multicolumn{5}{|c|}{ Weighted Statistics } \\
\hline R-squared & 0,163927 & \multirow{5}{*}{\multicolumn{2}{|c|}{$\begin{array}{l}\text { Mean dependent var } \\
\text { S.D. dependent var } \\
\text { Sum squared resid } \\
\text { Durbin-Watson stat }\end{array}$}} & 0,039995 \\
\hline Adjusted R-squared & 0,130815 & & & 0,117020 \\
\hline S.E. of regression & 0,108912 & & & 1,198054 \\
\hline F-statistic & 4,950699 & & & 1,512939 \\
\hline Prob(F-statistic) & 0,001099 & & & \\
\hline
\end{tabular}

\section{Pengujian Hipotesis}

\section{Koefisien Determinasi}

Berdasarkan tabel 6, nilai adjusted $r$-squared adalah 0,130815 atau 13,0815\%. Hal ini menunjukkan kemampuan variabel independen yang terdiri dari asimetri informasi, risiko litigasi, investment opportunity set, dan intensitas modal dalam menjelaskan variabel dependen yaitu konservatisme akuntansi sebesar $13,0815 \%$, sedangkan sisanya dijelaskan oleh variabel lain yang tidak diteliti.

\section{Uji Statistik F}

Berdasarkan tabel 6, diperoleh nilai probabilitas (F-statistic) sebesar 0,001099 lebih kecil dari 0,05, sehingga $\mathrm{H}_{0}$ ditolak. Oleh sebab itu, variabel independen yaitu asimetri informasi, risiko litigasi, investment opportunity set, dan intensitas modal berpengaruh secara simultan terhadap konservatisme akuntansi. 
Studi Akuntansi \& Keuangan Indonesia Uji Statistik $t$

Berdasarkan tabel 6, dapat disimpulkan pengaruh variabel independen terhadap variabel dependen secara parsial. Variabel asimetri informasi $\left(X_{1}\right)$ memiliki nilai probabilitas sebesar 0,0036 < 0,05 dan memiliki nilai koefisien regresi sebesar 0,168415. Oleh sebab itu, dapat disimpulkan bahwa asimetri informasi $\left(\mathrm{X}_{1}\right)$ berpengaruh positif terhadap konservatisme akuntansi. Variabel risiko litigasi $\left(\mathrm{X}_{2}\right)$ memiliki nilai probabilitas sebesar $0,0008<0,05$ dan memiliki nilai koefisien regresi sebesar 0,046491. Oleh sebab itu, dapat disimpulkan bahwa risiko litigasi $\left(X_{2}\right)$ berpengaruh negatif terhadap konservatisme akuntansi. Variabel investment opportunity set $\left(\mathrm{X}_{3}\right)$ memiliki nilai probabilitas sebesar $0,2597>0,05$ dan nilai koefisien regresi sebesar $-0,228929$. Oleh sebab itu, dapat disimpulkan bahwa investment opportunity set $\left(\mathrm{X}_{3}\right)$ tidak berpengaruh terhadap konservatisme akuntansi. Variabel intensitas modal $\left(\mathrm{X}_{4}\right)$ memiliki nilai probabilitas sebesar $0,1200>0,05$ dan nilai koefisien regresi sebesar 0,048953 . Oleh sebab itu, dapat disimpulkan bahwa intensitas modal $\left(\mathrm{X}_{4}\right)$ tidak berpengaruh terhadap konservatisme akuntansi

\section{Diskusi Hasil Penelitian}

Pengaruh Asimetri Informasi terhadap Konservatisme Akuntansi

Berdasarkan tabel 6, variabel asimetri informasi $\left(\mathrm{X}_{1}\right)$ memiliki nilai signifikansi sebesar $0,0036<0,05$ dan nilai koefisien regresi sebesar 0,168415 . Hal tersebut menunjukkan bahwa asimetri informasi $\left(\mathrm{X}_{1}\right)$ berpengaruh positif terhadap konservatisme akuntansi, maka $\mathrm{H}_{1}$ diterima. Asimetri informasi terjadi ketika terdapat ketidakseimbangan informasi antara pihak manajer dengan investor dalam pengambilan keputusan. Manajer sebagai pihak internal perusahaan lebih memahami keadaan dan prospek perusahaan masa akan datang yang memengaruhi keputusan investor dalam membeli sekuritas perusahaan. Oleh sebab itu, jika semakin besar ketidakseimbangan informasi antara pihak internal dan investor maka pihak internal akan semakin berhati-hati melaporkan laporan keuangannya (konservatif). Sebaliknya, jika semakin rendah ketidakseimbangan informasi yang terjadi maka penerapan konservatisme juga semakin rendah. Hasil penelitian ini mendukung penelitian Isniawati et al. (2016) dan LaFond dan Watts (2008).

Pengaruh Risiko Litigasi terhadap Konservatisme Akuntansi 
Studi Akuntansi \& Keuangan Indonesia

Berdasarkan tabel 6, variabel risiko litigasi $\left(\mathrm{X}_{2}\right)$ memiliki nilai signifikansi sebesar 0,0008< 0,05 dan memiliki nilai koefisien regresi sebesar -0,046491. Hal tersebut menunjukkan bahwa risiko litigasi $\left(\mathrm{X}_{2}\right)$ berpengaruh negatif terhadap konservatisme akuntansi, maka $\mathrm{H}_{2}$ ditolak. Hasil tersebut tidak mendukung hipotesis penelitian yang menyatakan bahwa risiko litigasi berpengaruh positif terhadap konservatisme akuntansi. Risiko litigasi merupakan risiko yang akan dihadapi perusahaan dan dapat menimbulkan ancaman litigasi dari pihak yang merasa dirugikan, sehingga perusahaan dapat mengeluarkan biaya yang tinggi. Risiko litigasi dapat memicu seorang manajer untuk menerapkan konservatisme akuntansi dalam pelaporan keuangan. Hasil penelitian yang didapatkan bertentangan dengan hipotesis penelitian. Berdasarkan hasil statistik deskriptif menunjukkan bahwa perusahaan sektor barang konsumsi periode 2016-2018 memiliki nilai Debt to Equity Ratio (DER) yang rendah, sehingga pendanaan perusahaan oleh pemegang saham lebih tinggi dibandingkan pendanaan melalui kreditur. Oleh sebab itu, perusahaan akan memiliki tanggungjawab yang tinggi terhadap investor. Perusahaan akan berhati-hati dalam melaporkan keuangannya (lebih konservatif) agar investor tidak merasa dirugikan. Hasil penelitian ini mendukung penelitian Dewi et al. (2014) yang menunjukkan risiko litigasi memiliki pengaruh negatif terhadap konservatisme akuntansi.

\section{Pengaruh Investment Opportunity Set terhadap Konservatisme Akuntansi}

Berdasarkan tabel 6 , variabel investment opportunity set $\left(\mathrm{X}_{3}\right)$ memiliki nilai signifikansi sebesar 0,2597 > 0,05 dan nilai koefisien regresi sebesar -0,228929. Hal tersebut menunjukkan bahwa investment opportunity set $\left(\mathrm{X}_{3}\right)$ tidak berpengaruh terhadap konservatisme akuntansi, maka $\mathrm{H}_{3}$ ditolak. Investment opportunity set tidak berpengaruh terhadap konservatisme akuntansi berarti tinggi atau rendahnya nilai investment opportunity set perusahaan tidak akan memengaruhi penerapan konservatisme akuntansi perusahaan tersebut. Hal tersebut dikarenakan keputusan investasi di masa yang akan datang akan memengaruhi nilai perusahaan, sehingga perusahaan akan melaporkan keuangannya dengan baik tanpa mempertimbangkan penerapan konservatisme akuntansi. Selain itu, berdasarkan hasil statistik deskriptif, perusahaan sektor barang konsumsi menunjukkan bahwa perusahaan belum memaksimalkan pilihan kesempatan investasi yang dimiliki karena terdapat 62 observasi yang memiliki nilai investment opportunity set di bawah rata-rata. Hal tersebut menunjukkan bahwa perusahaan memiliki pertumbuhan investasi yang rendah. Hasil penelitian ini 
Studi Akuntansi \& Keuangan Indonesia mendukung penelitian Dwitayanti dan Fahlefi (2015) bahwa investment opportunity set tidak memengaruhi konservatisme akuntansi.

\section{Pengaruh Intensitas Modal terhadap Konservatisme Akuntansi}

Berdasarkan tabel 6, intensitas modal $\left(\mathrm{X}_{4}\right)$ memiliki nilai signifikansi sebesar 0,1200 $>0,05$ dan nilai koefisien regresi sebesar 0,048953. Hal tersebut menunjukkan bahwa intensitas modal $\left(\mathrm{X}_{4}\right)$ tidak berpengaruh terhadap konservatisme akuntansi, maka $\mathrm{H}_{4}$ ditolak. Intensitas modal tidak berpengaruh terhadap konservatisme akuntansi berarti tinggi atau rendahnya tingkat intensitas modal perusahaan tidak akan memengaruhi penerapan konservatisme akuntansi perusahaan tersebut. Hal tersebut dikarenakan penggunaan aktiva dalam menghasilkan penjualan yang efisien akan memengaruhi nilai perusahaan bagi investor dan kreditur. Oleh sebab itu, perusahaan akan menyajikan laporan keuangannya tanpa mempertimbangkan penerapan konservatisme akuntansi. Selain itu, berdasarkan hasil statistik deskriptif menunjukkan bahwa perusahaan belum memaksimalkan penggunaan aktiva untuk menghasilkan penjualan karena terdapat 55 observasi yang memiliki nilai intensitas modal di bawah rata-rata. Hasil penelitian mendukung penelitian Murwaningsari dan Rachmawati (2017) bahwa intensitas modal tidak memengaruhi konservatisme akuntansi.

\section{Kesimpulan, Implikasi, dan Keterbatasan}

Hasil penelitian menunjukkan bahwa asimetri informasi berpengaruh positif terhadap konservatisme akuntansi, risiko litigasi berpengaruh negatif terhadap konservatisme akuntansi, investment opportunity set dan intensitas modal tidak berpengaruh terhadap konservatisme akuntansi pada perusahaan sektor barang konsumsi yang terdaftar di Bursa Efek Indonesia periode 2016-2018.

Keterbatasan pada penelitian ini adalah variabel yang digunakan yaitu asimetri informasi, risiko litigasi, investment opportunity set, dan intensitas modal hanya mampu menjelaskan variabel dependen sebesar 13,0815\%, sedangkan sisanya dijelaskan oleh variabel lain yang tidak diteliti oleh peneliti. Peneliti selanjutnya diharapkan menggunakan variabel lain yang tidak diteliti oleh peneliti misalnya manajemen laba, pajak, dan company growth. Berdasarkan hasil penelitian, konservatisme 
Studi Akuntansi \& Keuangan Indonesia akuntansi menunjukkan tren yang menurun. Oleh sebab itu, diharapkan peneliti selanjutnya tidak hanya meneliti konservatisme akuntansi tetapi juga meneliti prudence.

Hasil penelitian ini juga diharapkan dapat memberikan implikasi bagi perusahaan. Perusahaan diharapkan untuk memerhatikan asimetri informasi dan risiko litigasi karena hal tersebut dapat memengaruhi tingkat konservatisme akuntansi yang diterapkan. Perusahaan dengan tingkat asimetri informasi yang tinggi perlu meningkatkan kehati-hatian dalam menyajikan laporan keuangan (konservatif) agar tidak ada pihak yang dirugikan dan menghindari ancaman litigasi dari pihak yang dirugikan. Bagi investor, diharapkan agar selektif dalam mengambil keputusan berinvestasi dengan memerhatikan tingkat asimetri informasi perusahaan karena sebagian besar perusahaan sektor barang konsumsi memiliki tingkat asimetri informasi di bawah rata-rata. Hal ini menunjukkan perusahaan memiliki pertumbuhan investasi yang kurang baik. Selain itu, bagi kreditur diharapkan untuk memerhatikan tingkat risiko litigasi perusahaan karena jika risiko litigasi tinggi maka tingkat hutang yang dimiliki perusahaan semakin tinggi pula dan akan memengaruhi kebijakan perusahaan dalam menyajikan laporan keuangan.

\section{Daftar Pustaka}

Alfian, A., dan Sabeni, A. (2013). Analisis Faktor-Faktor yang Berpengaruh terhadap Pemilihan Konservatisme Akuntansi. Diponegoro Journal of Accounting, 2(3), 1-10.

Andreas, H. H., Ardeni, A., dan Nugroho, P. I. (2017). Konservatisme Akuntansi di Indonesia. Jurnal Ekonomi dan Bisnis, 20(1), 1-22.

Aristantia, D., dan Putra, I. P. (2015). Investment Opportunity Set dan Free Cash Flow pada Tingkat Pembayaran Dividen Perusahaan Manufaktur. E-Jurnal Akuntansi Universitas Udayana, 11(1), 220234.

Dewi, L. K., Herawati, N. T., dan Sinarwati, N. K. (2014). Faktor-Faktor yang Berpengaruh terhadap Konservatisme Akuntansi pada Perusahaan Manufaktur di BEI. Jurnal Ilmiah Mahasiswa Akuntansi, 2(1), $1-12$

Dwitayanti, Y., dan Fahlevi, R. (2015). Pengaruh Kepemilikan Manajerial, Investment Opportunity Set (IOS), Price to Book Ratio, dan Political Cost terhadap Konservatisma Akuntansi. Jurnal Akuntanika, 2(1), 31-43.

Financial Accounting Standards Board. (1980). Statement of Financial Accounting Concepts No. 2 [online]. Tersedia:

https://www.fasb.org/jsp/FASB/Document_C/DocumentPage?cid=1218220132599\&acceptedDisclaim er=true [21 November 2019]

Hendriksen, E. S., dan Breda, M. F. (2014). Teori Akunting. Tangerang: Interaksa.

Hermawan, A., dan Yusran, H. L. (2017). Penelitian Bisnis Pendekatan Kuantitatif. Depok: Kencana.

Isniawati, A., Rahmawati, dan Budiatmanto, A. (2016). Pengaruh Asimetri Informasi dan Analyst Coverage terhadap Konservatisme Akuntansi. Jurnal Akuntansi dan Auditing Indonesia, 20(2), 99-109.

Jensen, M., dan Meckling, W. (1976). Theory of the Firm: Managerial Behavior, Agency Costs and Ownership Structure. Journal of Financial Economics, 3(4), 305-360.

Kartika, I. Y., Subroto, B., dan Prihatiningtyas, Y. W. (2015). Analisa Kepemilikan Terkonsentrasi dan Asimetri Informasi terhadap Konservatisme Akuntansi. Jurnal Akuntansi Multiparadigma, 6(3), 341-511. 
Studi Akuntansi \& Keuangan Indonesia

LaFond, R., dan Watts, R. (2008). The Information Role of Conservatism. The Accounting Review, 83(2), 447478.

Murwaningsari, E., dan Rachmawati, S. (2017). The Influence of Capital Intensity and Investment Opportunity Set toward Conservatism with Managerial Ownership as Moderating Variable. Journal of Advanced Management Science, 5(6), 445-451.

Nidar, S. R. (2016). Manajemen Keuangan Perusahaan Modern. Bandung: Pustaka Reka Cipta.

Pratama, A., Norita, dan Nurbaiti, A. (2016). Pengaruh Tingkat Kesulitan Keuangan, Risiko Litigasi, dan Growth Opportunities terhadap Konservatisme Akuntansi. e-Proceeding of Management, III(3), 33153323.

Purnama, W., dan Daljono. (2013). Pengaruh Ukuran Perusahaan, Rasio Leverage, Intensitas Modal, dan Likuiditas Perusahaan terhadap Konservatisme Perusahaan. Diponegoro Journal of Accounting, 2(3), $1-11$.

Ramadhoni, Y., Zirman, dan Mudrika. (2014). Pengaruh Tingkat Kesulitan Keuangan Perusahaan, Risiko Litigasi, Struktur Kepemilikan Manajerial, dan Debt Convenant terhadap Konservatisme Akuntansi. JOM Fekon, 1(2), 1-20.

Riza, B. (2004, 7 Juli). Bapepam Temukan Indikasi Pelanggaran dalam Kasus Indofarma. Koran Tempo [online]. Tersedia: https://koran.tempo.co/read/17444/bapepam-temukan-indikasi-pelanggaran-dalamkasus-indofarma?read=true [16 Januari 2020]

Samuel, dan Juliarto, A. (2015). Pengaruh Konvergensi IFRS dan Ukuran Perusahaan terhadap Tingkat Konservatisme Akuntansi. Akuntansi \& Auditing, 12(2), 74-88.

Saputra, R. E. (2016). Pengaruh Struktur Kepemilikan Manajerial, Kontrak Utang, Tingkat Kesulitan Keuangan Perusahaan, Peluang Pertumbuhan, Risiko Litigasi, dan Leverage terhadap Konservatisme Akuntansi. JOM Fekon, 3(1), 2207-2221.

Saputri, Y. D. (2013). Faktor-Faktor yang Mempengaruhi Pilihan Perusahaan terhadap Konservatisme Akuntansi. Accounting Analysis Journal, 2(2), 191-198.

Savitri, E. (2016). Konservatisme Akuntansi. Yogyakarta: Pustaka Sahila.

Sinambela, M. O., dan Almilia, L. S. (2018). Faktor-Faktor yang Mempengaruhi Konservatisme Akuntansi. Jurnal Ekonomi dan Bisnis, XXI(2), 289-312.

Sujarweni, W. (2015). Metodologi Penelitian Bisnis dan Ekonomi. Yogyakarta: Pustaka Baru Press.

Susanti, A., Satriawan, R., dan Azhari. (2016). Pengaruh Asimetri Informasi, Ukuran Perusahaan, Kepemilikan Manajerial, dan Capital Adequacy Ratio terhadap Manajemen Laba. JOM Fekon, 3(1), 477-491.

Susanto, B., dan Ramadhan, T. (2016). Faktor-Faktor yang Memengaruhi Konservatisme. Jurnal Bisnis dan Ekonomi, 23(2), 142-151.

Syahrul, Y. (2003, 8 Desember). Bapepam: Kasus Kimia Farma Merupakan Tindak Pidana. Tempo [online]. Tersedia: https://bisnis.tempo.co/read/33339/bapepam-kasus-kimia-farma-merupakan-tindak-pidana [16 Januari 2020]

Wareza, M. (2019, 29 Maret). Tiga Pilar dan Drama Penggelembungan Dana. CNBC Indonesia [online]. Tersedia: https://www.cnbcindonesia.com/market/20190329075353-17-63576/tiga-pilar-dan-dramapenggelembungan-dana [13 November 2019]

Watts, R. (2003). Conservatism in Accounting Part II: Evidence and Research Opportunities. Accounting Horizons, 17(4), 287-301.

Zelmiyanti, R. (2014). Perkembangan Penerapan Prinsip Konservatisme dalam Akuntansi. JRAK, 5(1), $50-55$.

Zhang, J. (2007). The Contracting Benefits of Accounting Conservatism to Lenders and Borrowers. Journal of Accounting and Economics, 27-54. 